\title{
PENGARUH ENTREPRENEURIAL LEADERSHIP TERHADAP KINERJA UMKM KOTA SURABAYA MELALUI INOVASI
}

\author{
Yulvi Yusnia Anggriani \\ yulvianggriani@mhs.unesa.ac.id \\ Anang Kistyanto \\ Fakultas Ekonomi, Universitas Negeri Surabaya
}

\begin{abstract}
The economic movement in East Java which was dominated by MSMEs until December 2016 was able to increase the economy in Surabaya with many of these business people. This study aims to examine and analyze the effect of entrepreneurial leadership on organizational performance mediated by innovation in MSMEs guided by Cooperative Agency and Micro Enterprise City of Surabaya with Food and Beverage Business Sector. The type of this research is quantitative and explanatory research. The population of this research is the MSMEs guided by Dinas Koperasi dan Usaha Mikro Kota Surabaya with the Food and Beverage Business Sector. The questionnaire was distributed to 35 respondents and the statistical analysis used was Partial Least Squares (PLS) with smartPLS 3.0 software. The results of this study explain that entrepreneurial leadership has a significant positive effect on organizational performance. Entrepreneurial leadership has a significant positive effect on product innovation. Product innovation does not affect organizational performance. Entrepreneurial leadership does not affect organizational performance through product innovation. There is still inconsistency between this research result and previous research, the next research should analyze others variables that might affect entrepreneurial leadership in different sector.
\end{abstract}

Key words: entrepreneurial leadership; Innovation; Organizational performance

\begin{abstract}
ABSTRAK
Pergerakan ekonomi di Jawa Timur yang didominasi oleh UMKM hingga Desember 2016 mampu meningkatkan perekonomian di Surabaya dengan banyak pelaku bisnis ini. Penelitian ini bertujuan untuk menguji dan menganalisis pengaruh kepemimpinan kewirausahaan terhadap kinerja organisasi melalui inovasi dalam UMKM yang dipandu oleh Dinas Koperasi dan Usaha Mikro Kota Surabaya dengan Sektor Bisnis Makanan dan Minuman. Jenis penelitian ini adalah penelitian kuantitatif. Populasi penelitian ini adalah UMKM yang dipandu oleh Dinas Koperasi dan Usaha Mikro Kota Surabaya dengan Sektor Bisnis Makanan dan Minuman. Kuesioner dibagikan kepada 35 responden dan analisis statistik yang digunakan adalah Partial Least Squares (PLS) dengan perangkat lunak SmartPLS 3.0. Hasil penelitian ini menjelaskan bahwa kepemimpinan kewirausahaan memiliki pengaruh positif yang signifikan terhadap kinerja organisasi. Kepemimpinan kewirausahaan memiliki efek positif yang signifikan terhadap inovasi produk. Inovasi produk tidak mempengaruhi kinerja organisasi. Kepemimpinan wirausaha tidak mempengaruhi kinerja organisasi melalui inovasi produk. Masih ada ketidakkonsistenan antara hasil penelitian ini dan penelitian sebelumnya, penelitian selanjutnya harus menganalisis variabel lain yang mungkin mempengaruhi kepemimpinan kewirausahaan di sektor yang berbeda.
\end{abstract}

Kata kunci: kepemimpinan kewirausahaan; inovasi; kinerja organisasi

\section{PENDAHULUAN}

Salah satu faktor penting dalam organisasi adalah sumber daya manusia. Selain itu, salah satu faktor dalam pencapai- an tujuan organisasi perusahaan juga bergantung pada sumber daya manusia. Peran dari bidang sumber daya manusia ialah menciptakan sebuah perusahaan yang ung- 
gul serta proses pertumbuhan yang berkelanjutan. Demi terwujudnya suatu tujuan perusahaan sesuai dengan visi dan misi yang telah dirumuskan bergantung pada peran sumber daya manusianya. Hal ini dimaksudkan agar perusahaan tetap dapat mempertahankan kinerjanya dalam kondisi persaingan global. Kinerja organisasi ialah suatu kemampuan perusahaan dalam mencapai tujuan serta sasarannya (Suhag et al., 2017).

Kinerja organisasi adalah salah satu tolok ukur mengenai bagaimana suatu usaha mencapai setiap tujuannya. Peran dari pemimpin sangatlah penting dalam hal ini, tidak hanya secara internal bagi organisasi yang bersangkutan, namun juga secara eksternal dalam upaya menghadapi tantangan dari pihak luar organisasi, dimana hal ini dimaksudkan untuk meningkatkan kinerja organisasi demi mencapai tujuannya (Sutrisno, 2009). Selain itu, diperlukan gaya kepemimpinan yang cocok bagi sebuah oerganisasi agar tercapainya target kinerja yang telah ditetapkan sebelumnya.

Seorang pemimpin haruslah mampu memberdayakan para bawahannya untuk merealisasikan suatu visi-misi organisasi, dalam hal ini gaya kepemimpinan menjadi faktor kuncinya. Gaya entrepreneurial leadership merupakan salah satu gaya kepemimpinan khusus yang dapat fleksibel diterapkan dalam sebuah organisasi (Gupta et al., 2004). Renko et al., (2015) menyatakan bahwa entrepreneurial leadership ialah proses pertemuan antara kepemimpinan dan kewirausahaan. Karakteristik seorang pengikut pemimpin organisasi dalam mendemonstrasikan perilaku entrepreneurial merupakan aspek penting dalam kesuksesan gaya kepemimpinan ini, selain konteks perilaku pemimpin itu sendiri.

Inovasi, awal kebijakan serta gagasan, perkembangan strategi, kesejahteraan aumber daya manusia, dan pemaksimalan Kentungan merupakan karakteristik kepemimpinan pada abad 21 (Mgeni dan Nayak, 2015). Seorang pemimpin yang inovatif akan cenderung mampu membawa suatu organisasi untuk dapat bertahan dalam segala situasi dan kondisi. Perilaku inovatif merupakan perilaku yang mengkreasikan serta mengkombinasikan hal baru, apakah itu dalam bentuk produk atau jasa yang dapat memberikan nilai tambah dalam segi sosial maupun ekonomis. Perubahan lingkungan, pertumbuhan dan kehidupan ekonomi dalam setiap organisasi ditentukan atas proses inovasinya. Tujuan dari proses inovasi adalah untuk memastikan bahwa sebuah organsasi dapat menyediakan produk atau suatu pelayanan yang maksimal kepada setiap konsumen, serta mempertahankan Kenggulan kompetitif organisasi melalui peningkatan kinerja organisasi yang berkelanjutan.

Kewirausahaan memiliki banyak aspek. Ini dapat digambarkan sebagai proses penciptaan bisnis (Kuratko, 2005: 577). Ini adalah pilihan karir ketika pengusaha memutuskan untuk menukar tempat kerjanya dengan kemungkinan lain dan untuk memastikan kelangsungan hidup dan perkembangannya sendiri. Ini adalah cara memanfaatkan atau bahkan menciptakan peluang bisnis. Bosma et al., (2012: 15) mendefinisikan kewirausahaan sebagai proses dinamis di mana peluang bisnis terusmenerus dilahirkan dan kewirausahaan adalah peluang untuk menghadapi bisnis dan kebutuhan individu di pasar. Untuk generasi dan kinerja perusahaan baru, selain faktor lingkungan, faktor pribadi juga penting (Baum et al., 2001; Hankinson et al., 1997; Hussin, 1997; McClelland, 1961; Olson dan Bosserman, 1984).

Dilansir pada laman (Jawa Pos, 2019), ketangguhan perekonomian sebuah negara salah satu indikatornya bisa dilihat dari rasio jumlah pengusaha dengan jumlah penduduknya. Rata-rata negara maju yang memiliki ekonomi stabil, memiliki rasio 14 persen, atau 14 persen jumlah penduduk di negara tersebut adalah pengusaha. Sementara Indonesia rasio jumlah pengusaha masih rendah, meski dari tahun ke tahun jumlahnya menunjukkan tren kenaikan.

Sektor usaha kecil dan menengah (UKM) mendominasi pergerakan ekonomi di Jawa Timur dengan angka 98,64\% sesuai 
hasil pendaftaran sensus ekonomi 2016 (SE2016) yang dilakukan Badan Pusat Statistik (BPS) setempat. Kategori usaha perdagangan besar dan eceran mendominasi kategori usaha dengan nilai sebesar 2,08 juta $(44,58 \%)$. Selain itu, kinerja UKM mengalami kenaikan dibandingkan tahun-tahun sebelumnya dengan jumlah total yang saat ini mencapai 4,21 juta usaha dari total usaha atau perusahaan di Jatim yang mencapai 4,57 juta (Surabaya, 2017).

Meskipun saat ini perekonomian nasional mengalami perlambatan pertumbuhan ekonomi dengan banyaknya pelaku usaha, kota Surabaya sebagai ibu kota Jawa Timur tetap bertahan dan tumbuh dengan nilai $92 \%$ pelaku usaha kecil menengah (UKM) (Wirajaya, 2016).

Peran UMKM terbukti cukup mampu dalam meningkatkan perekonomian di Surabaya dan pelaku usaha yang bergelut dengan bidang usahanya. Salah satu faktor terpenting untuk evaluasi dan merencanakan tujuan di masa depan bergantung pada kinerja organisasinya. Selain itu, diperlukannya suatu gaya kepemimpinan yang sesuai agar dapat menciptakan keefektifan dalam pencapaian kinerja UMKM yang maksimal. Gaya entrepreneurial leadership dianggap perlu diterapkan oleh seorang wirausaha dalam mengelola UMKM, karena entrepreneurial leadership memiliki kapabilitas untuk memotivasi orang lain agar dapat menciptakan peluang yang inovatif dan adaptif dengan perubahan, sehingga diharapkan kinerja UMKM menjadi lebih optimal.

Selain itu, inovasi juga berpengaruh terhadap kinerja organisasi, hal ini dikarenakan agar produk UMKM dapat bersaing di pasaran sehingga dapat bertahan dalam perubahan lingkungan dan persaingan usaha. Salah satu faktor terpenting yang menonjol pada proses kewirausahaan adalah perilaku inovasi. Inovasi dipandang sebagai salah satu faktor kunci keberlangsungan serta daya saing suatu negara maupun organisasi (Ranto, 2017). Inovasi produk yang merupakan pengembangan dan pengenalan produk baru menurut Suendro
(2011) banyak diadaptasi oleh UMKM yang ada di Kota Surabaya. Seperti halnya yang terdapat pada UMKM Denil Pudding Surabaya yang berinovasi produknya dengan kopi jelly atau cappuccino cincau yang dulunya pernah trend dikemas dengan botol yang bervariatif dan dengan rasa yang bervariasi tidak hanya capucino juga greentea, kopi, tiramisu yang diberi jelly untuk mengikuti perkembangan zaman sekarang. UMKM ini juga membuat pudding dengan berbagai macam bentuk, berbeda dengan yang lain UMKM ini mengembangkan pudding dengan gambar wajah sesuai pesanan.

Menurut Basrowi (2009) mengatakan kemampuan seseorang dalam berkreativitas juga dapat diterapkan dalam kewirausahaan, kemampuan seseorang untuk memimpin harus diimbangi oleh perilaku tertentu yang dikenal sebagai kewirausahaan dimensi inovasi.

Salah satu faktor yang meningkatkan kinerja organisasi lainnya yaitu entrepreneurial leadership. Berdasarkan hasil wawancara dengan ibu Aminah selaku pemilik usaha yang berlokasi di Surabaya menuturkan bahwa, ia pernah mengalami beberapa kali kegagalan dalam usahanya, namun ia tidak patah semangat dan terus berusaha menekuni usaha semanggi yang didirikannya. Ibu Aminahpun berinovasi dengan semanggi instannya, hal ini menjadi sebuah produk inovatif pertama yang ada di Surabaya. Berdasarkan fenomena ini membuktikan bahwa entrepreneurial leadership dapat membuat adanya peningkatan kinerja dari usaha yang dijalankan oleh seorang pelaku usaha.

Entrepreneurial leadership sangat penting dimiliki pemilik usaha agar dapat menciptakan gebrakan baru dan perubahan serta inisiatif, dengan inovasi tersebut yang menjadikan usaha lebih berkembang. Namun, kemampuan entrepreneurial leadership terhadap kinerja melalui inovasi pada UMKM di Surabaya tidak banyak mendapat perhatian oleh sivitas akademika. Berdasarkan uraian yang telah dijelaskan diatas Feno- 
mena UMKM pada bidang usaha makanan dan minuman yang dapat bertahan hingga saat ini dengan banyaknya pesaing membuat peneliti tertarik untuk meneliti kepemimpinan yang ada pada pemilik usaha kecil mikro menengah di Surabaya.

Penelitian ini memilih untuk meneliti UMKM Binaan Dinas Koperasi dan Usaha Mikro Kota Surabaya bidang usaha makanan, dikarenakan trend makanan saat ini yang berkembang pesat serta variasi makanan yang banyak dan cepat mengikuti perkembangan zaman sehingga membuat pemilik usaha harus mampu menciptakan inovasi yang berbeda agar dapat memuaskan konsumen dengan produk inovasinya. Inovasi produk merupakan salah satu inovasi yang penting dilakukan oleh UMKM dikarenakan inovasi produk merupakan salah satu cara penting bagi perusahaan agar tetap dapat beradaptasi dengan pasar (Suendro, 2011).

\section{TINJAUAN TEORITIS}

\section{Entrepreneurial Leadership}

Definisi paling awal dari seorang pemimpin wirausaha adalah oleh Lippitt (1987), yang mendefinisikannya sebagai orang yang mampu berinovasi, fokus pada tugas, mengambil risiko, memikul tanggung jawab pribadi dan memiliki orientasi ekonomi. Femald dan Solomon (1996) mengajukan definisi lain tentang kepemimpinan kewirausahaan. Kepemimpinan kewirausahaan didefinisikan sebagai asosiasi pengusaha dan fungsi kepemimpinan yang menyediakan produk baru, layanan atau pengembangan organisasi.

Lebih lanjut mereka menambahkan bahwa kepemimpinan kewirausahaan menitik beratkan pada ide dan konsep yang biasanya terkait dengan masalah, yang cenderung dikaitkan dengan perilaku individu seperti pemecahan masalah, pengambilan keputusan, inisiatif strategis, visi, dan pengambilan risiko. Peneliti lain memberikan definisi yang hampir sama tentang kepemimpinan kewirausahaan seperti (Femald dan Solomon, 1996; Kuratko dan Hornsby, 1996) dalam diskusi mereka tentang bagaimana mengembangkan kepemimpinan kewirausahaan dalam organisasi kontemporer. Hisrich dan Grachev (1996) juga menawarkan diskusi serupa seperti (Kuratko dan Hornsby, 1996; Femald dan Solomon, 1996) dalam diskusi mereka tentang kepemimpinan kewirausahaan dalam usaha baru dalam ekonomi global.

Kepemimpinan kewirausahaan adalah konstruksi baru untuk penelitian (Fernald et al., 2005), dan sedikit yang belum diketahui tentang sifat atau efeknya (Bagheri dan Pihie, 2011; Gupta et al., 2004). Istilah tersebut dibentuk dari dua komponen, yaitu "kewirausahaan" dan "kepemimpinan". Menurut Kuratko (2007), kewirausahaan adalah proses yang melibatkan visi, perubahan, dan kreasi. Ini terkait erat dengan kepemimpinan, karena pemimpin dituntut untuk mengeksplorasi, mengevaluasi dan menangkap peluang untuk menciptakan proses dan produk yang menghasilkan manfaat bagi karyawan, tim, dan organisasi (Wang et al., 2012).

Fontana et al., (2017) menyatakan bahwa entrepreneurial leadership ialah proses membagi sebuah tujuan tentang kemungkinan suatu organisasi dimasa depan yang dapat dieksploitasi agar mampu mempertahankan daya saingnya. Selain itu, dalam konteks mempengaruhi orang lain terhadap suatu tujuan melalui adanya komunikasi yang efektif untuk mengenali setiap peluang yang ada. Mokhber et al., (2016) mengemukakan bahwa entrepreneurial leadership merupakan pertemuan antara kepemimpinan dengan kewirausahaan.

Karakteristik pengikut seorang pemimpin dalam mendemonstrasikan perilaku entrepreneurial menjadi salah satu faktor kesuksesan entrepreneurial leadership. Kepemimpinan wirausaha penting bagi sebuah organisasi untuk mendorong pengembangan tinjauan kepemimpinan wirausaha mereka disemua tingkatan dalam organisasi untuk memastikan bahwa manajemen inovasi / proses inovasi dikelola secara efektif (Indawati et al., 2018). 
Kepemimpinan kewirausahaan yang baik juga dapat meningkatkan kinerja perusahaan (Kistyanto et al., 2018). Leitch dan Volery (2017) berpendapat bahwa entrepreneurial leadership ialah proses melibatkan penetapan suatu tujuan yang jelas, memberdayakan orang, menciptakan peluang, melestarikan keakraban organisasi, serta mengembangkan sebuah sistem sumber daya manusia yang efektif.

\section{Inovasi}

Baregegh et al., (2009: 1334), inovasi merupakan suatu proses tingkatan transformasi ide organisasi untuk dapat meningkatkan produk, layanan atau proses, agar terus dapat berkembang, bersaing, serta menjadi pembeda. Semuel et al., (2017) memaparkan inovasi ialah suatu proses dalam penciptaan ide, gagasan, pengembangan teknologi, pembuatan, serta pemasaran dari sebuah produk, proses, pembuatan atau alat-alat baru. Inovasi sangat penting bagi organisasi untuk mempertahankan keunggulan dalam lingkungan yang sangat kompetitif (Kistyanto et al., 2021).

Perubahan lingkungan, pertumbuhan dan kehidupan ekonomi dalam setiap organisasi berkaitan dengan proses inovasi (Fontana et al., 2017). Suendro (2011) mengemukakan inovasi produk ditunjukkan pada pengembangan dan pengenalan produk baru berupa perubahan desain, komponen, dan arsitektur produk. Inovasi produk merupakan salah satu cara penting bagi perusahaan agar tetap dapat beradaptasi dengan pasar, teknologi, serta persaingan (Suendro, 2011).

\section{Kinerja Organisasi}

Selden dan Sowa (2004) menjelaskan kinerja organisasi sebagai suatu kapabilitas dari sebuah organisasi yang secara efektif demi tercapainya cita-cita dan tujuannya. Berdasarkan hasil review dari literatur, telah teridentifikasi bahwa kinerja suatu organisasi diukur menggunakan sebuah pengukuran secara obyektif. Menurut Semuel et al., (2017) kinerja organisasi mengacu pada suatu kemampuan sebuah perusahaan dalam mencapai keuntungan pendapatan yang tinggi, market share yang sangat luas, kualitas produk, hasil keuangan yang cukup baik, keberlanjutan sebuah perusahaan pada setiap waktu, serta tercapainya suatu tujuan dengan strategi yang relevan.

Gunaedi dan Kistyanto (2018) mendefinisikan kinerja yaitu output dari proses kerja yang telah dilakukan individu dalam periode yang ditargetkan dengan menggunakan kreativitas untuk mencapai tujuan kerja perusahaan. Kinerja ialah suatu pencapaian atas prestasi kerja, baik itu secara kualitas ataupun kuantitas yang telah dilakukan atas dasar tujuan pekerjaan yang dalam hal ini telah ditetapkan perusahaan (Rahman dan Kistyanto, 2019).

Kinerja mengacu pada pencapaian hasil yang ditargetkan yang menyertai rencana; dengan demikian, evaluasi kinerja dianggap sebagai pusat manajemen kinerja (Cardy dan Leonard, 2015). Selain itu, kinerja individu dan organisasi sangat bergantung pada semua kebijakan organisasi, aplikasi, dan struktur organisasi.

Selain itu, kinerja organisasi merupakan pola pikir pelengkap yang merupakan pendekatan konfigurasi sumber daya manusia strategis yang berisi jenis kegiatan SDM, sebagaimana dihadapkan dengan aktivitas individu, yang diperlukan untuk mencapai tujuan perusahaan (Anitha, 2014). Kinerja organisasi dianggap sebagai salah satu ukuran produktivitas dengan mempertimbangkan partisipasi karyawan perusahaan (Oyemomi et al., 2016). Ini adalah kriteria pengembangan organisasi. Ini menjelaskan sejauh mana suatu organisasi mencapai tujuannya (Choudhary et al., 2013). 
Sumber: diolah penulis

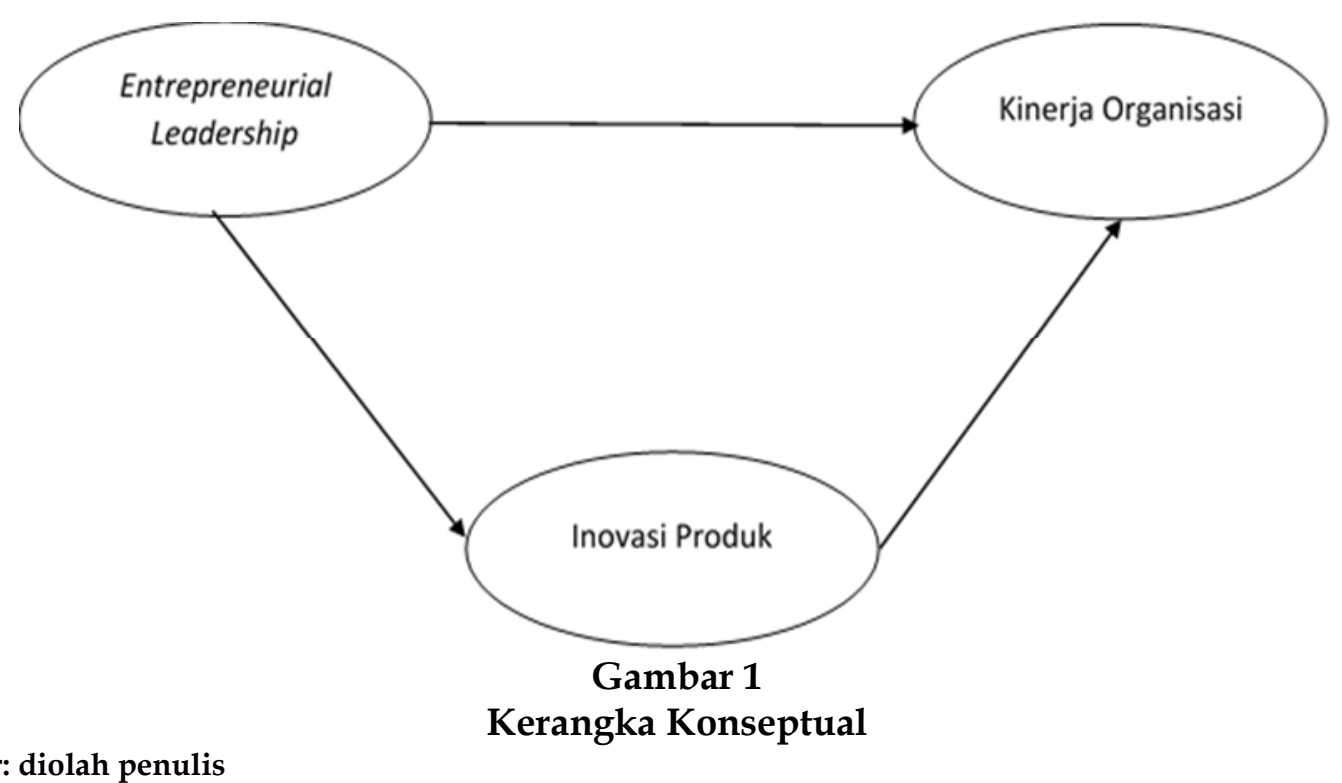

\section{Pengembangan Hipotesis}

Entrepreneurial leadership merupakan suatu gaya kepemimpinan untuk memengaruhi orang lain pada suatu tujuan dengan komunikasi yang efektif untuk mengenali peluang. Selain itu, membagi sebuah tujuan mengenai apa yang terjadi terhadap organisasi di masa yang akan datang agar memiliki daya saing (Fontana et al., 2017). Hal ini berarti entrepreneurial leadership bisa mempengaruhi kinerja organisasi dimana seorang pemimpin dapat mengenali peluang sesuai dengan kapabilitas sebuah organisasi untuk mencapai cita-cita dan tujuan nya (Selden dan Sowa, 2004).

Rahim et al., (2015) mengemukakan bahwa terdapat pengaruh positif pada entrepreneurial leadership dengan kinerja organisasi. Gaya kepemimpinan yang diapatasi mampu meningkatkan kinerja dengan memahami hubungan keduanya. Mgeni dan Nayak (2015) menyatakan gaya kepemimpinan kewirausahaan berpengaruh positif terhadap kinerja organisasi. Menurut hasil penelitian yang dilakukan oleh Kistyanto et al., (2018) kepemimpinan wirausaha yang dimiliki oleh pendiri industri makanan dapat mempengaruhi kinerjanya, dibuktikan dengan faktor strategi sebagai indikator nilai tertinggi yang mempengaruhi peningkatan pertumbuhan penjualan.
Kepemimpinan kewirausahaan memotivasi karyawannya untuk bekerja lebih baik (Renko et al., 2015). Dengan bergerak secara strategis dan berfokus pada inisiatif kewirausahaan, para pemimpin tersebut dapat memastikan kinerja organisasi yang lebih baik (Miao et al., 2019; Rahim et al., 2015). Mereka mengeksploitasi lingkungan untuk menciptakan peluang, memanfaatkan perubahan, dan mengembangkan keunggulan kompetitif untuk kinerja yang lebih baik dan tahan lama (Sarabi et al., 2020). Penelitian tentang proses kepemimpinan kewirausahaan dan hasil prospektifnya cukup langka (Kim et al., 2017). Selain itu, terdapat kelangkaan literatur yang berfokus pada hubungan khusus ini sehingga perlu untuk dieksplorasi lebih jauh. Oleh karena itu, hipotesis berikut dikembangkan:

$\mathrm{H}_{1}$ : Entrepreneurial leadership berpengaruh positif terhadap kinerja organisasi

Selain memengaruhi kinerja organisasi, entrepreneurial leadership juga berpengaruh terhadap inovasi (Yusnita dan Wahyudin, 2017). Entrepreneurial leadership dapat pula digunakan sebagai upaya untuk meningkatkan daya saing UMKM di era global seperti saat ini. Menurut Leitch dan Volery (2017) entrepreneurial leadership merupakan suatu kemampuan untuk dapat mempengaruhi orang lain agar mampu mengelola sumber 
daya dengan strategis agar memaksimalkan kesempatan serta keuntungan.

Gaya entrepreneurial leadership perlu diterapkan, karena seseorang akan dapat mempunyai sebuah kapabilitas untuk dapat memotivasi orang lain dalam memaksimalkan peluang, menjadikan kreatif dan inovatif, serta cerdas dalam upaya beradaptasi untuk suatu perubahan. Kemampuan seseorang dalam berkreativitas dapat diterapkan dalam kewirausahaan, kemampuan seseorang untuk memimpin harus diimbangi dengan perilaku yang dikenal sebagai kewirausahaan dimensi inovasi (Basrowi, 2009). Inovasi dapat dikatakan sebagai salah satu faktor penentu pada proses kewirausahaan, serta inovasi dianggap sebagai faktor dominan keberlangsungan serta proses daya saing suatu negara maupun organisasi (Ranto, 2017). Oleh karena itu, hipotesis berikut dikembangkan:

$\mathrm{H}_{2}$ : Entrepreneurial leadership berpengaruh positif terhadap inovasi

Inovasi merupakan hal yang dapat memengaruhi kinerja organisasi. Menurut (Semuel et al., 2017) inovasi merupakan aktivitas yang berhubungan langsung dengan proses penciptaan suatu ide, pengembangan suatu teknologi, pembuatan suatu produk, serta pemasaran dari sebuah produk. Inovasi juga merupakan salah satu faktor penting dengan hubungannya secara langsung terhadap perubahan suatu lingkungan, pertumbuhan serta kehidupan perekonomian dalam suatu organisasi (Kotsemir dan Meissner, 2013). Salah satu inovasi yang penting dilakukan yaitu inovasi produk. Menurut Suendro (2011) inovasi produk merupakan salah satu cara penting bagi perusahaan agar tetap beradaptasi dengan pasar, teknologi, serta persaingan. Sehingga dalam hal ini inovasi sangat penting dalam meningkatkan kinerja organisasi dalam sebuah usaha.

Penelitian yang dilakukan Tuan et al., (2016) terdapat pengaruh positif terhadap kinerja perusahaan yang mendukung perusahaan. Suhag et al., (2017) dan Samad (2012) menghasilkan penelitian terdapat pengaruh positif antara inovasi terhadap kinerja organisasi. Inovasi yang merupakan proses kreativitas dalam menciptakan perubahan dan keunggulan kompetitif untuk meningkatkan kinerja organisasi (Semuel et al., 2017). Selain itu, hasil penelitian Rahman et al., (2020) menunjukkan bahwa inovasi dalam wujud perilaku kerja berkorelasi positif dan signifikan dengan kinerja karyawan. Oleh karena itu, hipotesis berikut dikembangkan:

$\mathrm{H}_{3}$ : Inovasi berpengaruh positif terhadap kinerja organisasi

Entrepreneurial leadership dapat memengaruhi kinerja organisasi melalui inovasi. Hal tersebut dikarenakan peran seorang pemimpin yang sangat diperlukan, tidak hanya bagi internal organisasi saja, melainkan juga dalam menghadapi berbagai macam tantangan dari pihak eksternal organisasi (Sutrisno, 2009).

Perilaku inovatif merupakan perilaku yang mengkreasikan serta mengkombinasikan sesuatu hal baru, apakah itu dalam bentuk produk maupun jasa yang mengandung nilai sosial dan ekonomi. Perilaku tersebut biasanya terdiri atas menghasilkan suatu ide, mendiskusikan suatu ide, serta mengimplementasikan ide tersebut dalam bentuk produk atau jasa. (Ranto, 2017). Sehingga entrepreneurial leadership dapat meningkatkan daya saing serta kinerja organisasi dengan mengimplementasikan inovasi sebagai salah satu cara untuk berkembang di persaingan global. Oleh karena itu, hipotesis berikut dikembangkan:

$\mathrm{H}_{4}$ : Entreprenurial leadership berpengaruh positif terhadap kinerja organisasi melalui inovasi

\section{METODE PENELITIAN}

Jenis penelitian ini adalah penelitian kuantitatif, yang diartikan sebagai metode penelitian untuk melalukan penelitian pada suatu populasi maupun sampel tertentu, teknik pengambilan sampel yang dilakukan secara random, pengumpulan data dengan instrumen penelitian, analisis data bersifat kuantitatif/statistik dengan maksud 
menguji hipotesis yang telah diajukan. (Sugiyono, 2016). Penelitian ini dilakukan dengan eksplanatori (explanatory research), yaitu berupaya untuk menjabarkan suatu objek secara komperhensif serta memperhatikan batasan penelitian yang ditetapkan (Yusnita dan Wahyudin, 2017).

Penelitian ini dilakukan pada UMKM Binaan Dinas Koperasi dan Usaha Mikro Kota Surabaya dengan menggunakan teknik purposive sampling dan cluster sampling dengan menggunakan sampel jenuh pengambilan sampel non probability samping dengan tipe purposive sampling melalui pendekatan judgment sampling. Dari pendekatan tersebut menghasilkan sebanyak 35 pemilik usaha dijadikan sampel dalam penelitian ini. Penelitian ini dilakukan pada tahun 2018.

Analisis data menggunakan pendekatan metode Structural Equation Model (SEM) dengan Partial Least Squares (PLS) yang didukung program software komputer Smart-PLS 3.0, dan SPSS 23.0 untuk analisis statistik demografi karakteristik responden dan analisis deskriptif variabel.

Semua item dinilai pada skala likert 5 poin, dengan responden menunjukkan setuju atau tidak setuju dengan setiap pernyataan $(1=$ sangat tidak setuju dan $5=$ sangat setuju). Metode tiga kotak dapat digunakan untuk mencari nilai kategorik dari semua variabel dengan interval rendah, sedang dan tinggi.

\section{Tabel 1}

\section{Karakteristik Responden}

\begin{tabular}{clcc}
\hline No & Karakteristik Responden & Freekuensi & Presentase \\
\hline \hline $\mathbf{1}$ & Jenis Kelamin : & & \\
& a. Pria & 9 & $25.7 \%$ \\
& b. Wanita & 26 & $74.3 \%$ \\
& Total & 35 & $100 \%$ \\
Usia : & 2 & \\
& a. $<30$ tahun & 16 & $45.7 \%$ \\
& b. Antara 30 - 40 tahun & 11 & $31.4 \%$ \\
& c. Antara 41 - 50 tahun & 6 & $17.1 \%$ \\
& d. > 51 tahun & 35 & $100 \%$ \\
Total & & \\
Pendidikan : & 17 & $48.6 \%$ \\
& a. SMA/SMK & 3 & $8.6 \%$ \\
b. Diploma (D1/D2/D3) & 15 & $42.9 \%$ \\
c. Sarjana (S1) & 0 & 0 \\
d. S2 & 0 & 0 \\
e. S3 & 35 & $100 \%$ \\
Total & & \\
Lama Usaha Beroperasi : & 26 & $74.3 \%$ \\
a. $\leq 5$ tahun & 9 & $25.7 \%$ \\
b. > 5 - 15 tahun & 0 & 0 \\
c. > 15 - 20 tahun & 0 & 0 \\
d. > 20 tahun & 35 & $100 \%$ \\
Total & & \\
\hline
\end{tabular}

Sumber: Output SPSS 23 
Dari tabel 1, disimpulkan berdasarkan jenis kelamin, 9 responden adalah pria dan 26 responden adalah wanita, kemudian berdasarkan kriteria usia, 2 responden berusia $<30$ tahun, 16 responden berusia antara 30 - 40 tahun, 11 responden berusia antara 41 - 50 tahun, dan 6 responden berusia > 51 tahun, selanjutnya berdasarkan pendidikan, 17 responden adalah lulusan SMA/SMK, 3 responden adalah lulusan Diploma (D1/D2 /D3), dan 15 responden adalah lulusan Sarjana (S1), sedangkan berdasarkan lama usaha beroperasi, 26 UMKM Binaan Dinas Koperasi dan Usaha Mikro Kota Surabaya telah beroperasi selama $\leq 5$ tahun dan 9 UMKM Binaan Dinas Koperasi dan Usaha Mikro Kota Surabaya telah beroperasi selama $>5-15$ tahun.

\section{ANALISIS DAN PEMBAHASAN}

Sebelum data dianalisis perlu dilakukan uji validitas dan reliabilitas isntrumen yang digunakan. Pengujian validitas pada conver- gent validity dikatakan valid jika outer loading 0,5 - ,6 sudah dianggap cukup. Selanjutnya untuk menguji reliabilitas indikator dan konstruk dilihat dari composite reliability dikatakan baik jika nilainya $\geq 0,70$, sedangkan nilai cronbach's alpha digunakan untuk melihat sejauh mana nilai tersebut tetap reliabel, dengan syarat nilai cronbach's alpha $>0,70$ agar data tersebut dikatakan memenuhi syarat reliabel (Ghozali \& Latan, 2015).

Data pada tabel 2 menunjukkan bahwa seluruh outer loading lebih dari 0.6 maka dapat disimpulkan bahwa seluruh indikator valid. Hasil composite reliability pada tabel 2 menunjukkan nilai $>0,70$ yang berarti semua variabel penelitian memiliki reliabilitas yang baik. Hasil juga menunjukkan bahwa nilai cronbach's alpha yang ada pada tabel 2 menunjukkan semua variabel memiliki nilai $>0,70$, sehingga seluruh variabel memenuhi cronbach's alpha dan data tersebut dikatakan reliabel.

Tabel 2

Hasil Uji Validitas dan Reliabilitas

\begin{tabular}{|c|c|c|c|c|}
\hline Variabel & $\begin{array}{c}\text { Outer } \\
\text { Loading }\end{array}$ & $\begin{array}{l}\text { Composite } \\
\text { Reliability }\end{array}$ & $\begin{array}{l}\text { Cronbach's } \\
\text { Alpha }\end{array}$ & Keterangan \\
\hline Entrepreneurial Leadership (X) & & \multirow{5}{*}{0.919} & \multirow{5}{*}{0.883} & \multirow{5}{*}{$\begin{array}{l}\text { Valid dan } \\
\text { Reliabel }\end{array}$} \\
\hline Framing the challenge (X1.1) & 0.883 & & & \\
\hline Absorbing uncertainty (X1.2) & 0.858 & & & \\
\hline Path clearing (X1.3) & 0.891 & & & \\
\hline Building Commitment (X1.4) & 0.805 & & & \\
\hline Inovasi (Z) & & \multirow{3}{*}{0.929} & \multirow{3}{*}{0.847} & \multirow{3}{*}{$\begin{array}{c}\text { Valid dan } \\
\text { Reliabel }\end{array}$} \\
\hline Radical Innovation(Z1.1) & 0.932 & & & \\
\hline Incremental Innovation (Z1.2) & 0.930 & & & \\
\hline Kinerja Organisasi (Y) & & \multirow{5}{*}{0.868} & \multirow{5}{*}{0.796} & \multirow{5}{*}{$\begin{array}{c}\text { Valid dan } \\
\text { Reliabel }\end{array}$} \\
\hline $\begin{array}{l}\text { Penjualan lebih tinggi dari pesaing } \\
\text { (Y1.1) }\end{array}$ & 0.861 & & & \\
\hline $\begin{array}{l}\text { Penjualan usaha tumbuh dengan baik } \\
\text { (Y1.2) }\end{array}$ & 0.844 & & & \\
\hline $\begin{array}{l}\text { Jumlah karyawan mengalami } \\
\text { kenaikan (Y1.3) }\end{array}$ & 0.811 & & & \\
\hline $\begin{array}{l}\text { Laba kotor mengalami kenaikan } \\
\text { (Y1.4) }\end{array}$ & 0.623 & & & \\
\hline
\end{tabular}


Tabel 3

Penilaian Deskriptif Responden

\begin{tabular}{lccc}
\hline \multicolumn{1}{c}{ Variabel } & $\begin{array}{c}\text { Jumlah } \\
\text { item }\end{array}$ & $\begin{array}{c}\text { Mean } \\
\text { Indicator }\end{array}$ & $\begin{array}{c}\text { Mean } \\
\text { Variabel }\end{array}$ \\
\hline Entrepreneurial Leadership (X) & & & \\
Framing the challenge (X1.1) & 21 & 4.09 & \\
Absorbing uncertainty (X1.2) & & 4.30 & 4.25 (Tinggi) \\
Path clearing (X1.3) & & 4.37 & \\
Building Commitment (X1.4) & 8 & & \\
Inovasi (Z) & & 4.07 & 4.19 (Tinggi) \\
Radical Innovation (Z1.1) & & 4.30 & \\
Incremental Innovation (Z1.2) & & 3.74 & \\
Kinerja Organisasi (Y) & 4 & 4.14 & 3.84 (Tinggi) \\
Penjualan lebih tinggi dari pesaing (Y1.1) & & 3.57 & \\
Penjualan usaha tumbuh dengan baik (Y1.2) & & 3.89 & \\
Jumlah karyawan mengalami kenaikan (Y1.3) & & & \\
Laba kotor mengalami kenaikan (Y1.4) & & & \\
\hline
\end{tabular}

Sumber: Output SPSS 23

Data diolah dengan mengacu pada rumus teori tindakan beralasan untuk menentukan nilai variabel sebelumnya, tabel 3 menunjukkan penilaian deskriptif respon pada masing masing variabel. Pada tabel 3 dapat dilihat bahwa variabel entrepreneurial leadership memiliki rata-rata sebesar 4,25 yaitu dalam kategori tinggi. Pada indikator path clearing nilai rata-rata indikator sebesar 4,37 yang berarti pemilik UMKM Binaan Dinas Koperasi dan Usaha Mikro Kota Surabaya dapat menjalin suatu hubungan dan berkomunikasi yang baik dengan banyak pihak. Pada indikator tersebut terdapat nilai-nilai yang terdiri dari diplomatic, effective bargainer, convicing, dan encouraging. Nilai rata-rata indikator absorbing uncertainty sebesar 4,30 yang didalamnya terdapat nilai performace oriented, ambitious, informed, dan has extra insight, hal ini menununjukkan bahwa pemilik usaha Binaan Dinas Koperasi dan Usaha Mikro Kota Surabaya yang mampu mengimplementasikan visi dan misi usaha bersamasama dengan karyawan disertai rasa tanggung jawab yang tinggi dari pemilik maupun karyawan. Nilai rata-rata indikator building commitment sebesar 4,25 yang terdapat nilai inspirational, enthusiastic, team builder, dan improvement oriented yang menunjukkan bahwa pemilik UMKM Binaan Dinas Koperasi dan Usaha Mikro Surabaya mampu menginspirasi orang lain di lingkungan sekitar dengan usaha yang dijalankannya. Nilai rata-rata indikator framing the challenge sebesar 4,09 yang berarti pemilik UMKM ditengah target usaha yang telah ditetapkan agar tercapai, namun tetap memperhatikan aspek realistis dalam keberlangsungan usahanya. Pada indikator ini juga terdapat nilai performance oriented, ambitious, informed, dan has extra insight.

Pada tabel 3 menunjukkan bahwa variabel inovasi menunjukkan rata-rata variabel 4,19 yang juga menunjukkan kategori tinggi. Incremental innovation termasuk dalam kategori paling tinggi dari indikator inovasi produk lainnya yaitu sebesar 4,30.

Sedangkan rata-rata indikator radical innovation pada penelitian, responden dengan variabel inovasi produk menunjukkan hasil yang tinggi dengan hasil statistik ratarata indikator 4,07. Hal tersebut membuktikan bahwa pemilik UMKM Binaan Dinas 
Koperasi dan Usaha Mikro Kota Surabaya pada dasarnya sebagian dari mereka melakukan inovasi terhadap produknya untuk mengikuti permintaan yang selalu berubah dan mengikuti trend yang sedang terjadi namun tetap memiliki keunikan dari produk mereka sendiri.

Sedangkan pada variabel kinerja organisasi menunjukkan bahwa variabel kinerja organisasi memiliki rata-rata sebesar 3,84 yang termasuk dikategorikan tinggi. Jika diuraikan indikator penjualan usaha tumbuh dengan baik memiliki nilai mean indikator tertinggi, yaitu 4,14, setelah itu indikator laba kotor mengalami kenaikan memiliki nilai mean 3,89, penjualan lebih tinggi dari pesaing sebesar 3,74, dan terendah yaitu indikator jumlah karyawan mengalami kenaikan sebesar 3,57.

Hal ini menunjukkan bahwa pemilik UMKM Binaan Dinas Koperasi dan Usaha Mikro Kota Surabaya dapat mengelola usahanya dengan baik melalui kepemimpinan maupun inovasi yang dijalankan, sehingga membuat peningkatan pada kinerja UMKM Binaan Dinas Koperasi dan Usaha Mikro Kota Surabaya dengan usaha yang dijalankan selama ini.

Berdasarkan tanggapan penilaian responden UMKM Binaan Dinas Koperasi dan Usaha Mikro Kota Surabaya mengenai variabel penelitian yang dimasukkan ke dalam Paket Statistik untuk Ilmu Sosial (SPSS) versi 23,0, semua mean indikator variabel maupun mean variabel laten termasuk dalam kategori tinggi.

Pada tabel 4, untuk menguji tingkat signifikansi, t-statistik untuk semua jalur dibuat menggunakan fungsi bootstrap Smart-PLS 3,0. Berdasarkan penilaian koefisien jalur dan pengaruh tidak langsung seperti yang ditunjukkan pada Tabel 4, dua hubungan langsung ditemukan memiliki nilai $\mathrm{t}>1,96$ dengan signifikansi $<0,05$, sedangkan satu hubungan lainnya memiliki nilai $\mathrm{t}<1,96$ dengan signifikansi $>0,05$.

Selanjutnya, dilakukan proses pemeriksaan jalur struktural untuk memeriksa hubungan antara variabel yang dihipotesiskan. Pada pembahasan sebelumnya, kepemimpinan kewirausahaan diduga berhubungan positif dengan kinerja organisasi. Besarnya nilai $t$-Statistics pengaruh entrepreneurial leadership terhadap kinerja UMKM Binaan Dinas Koperasi dan Usaha Mikro Kota Surabaya sebesar 2,072 $\geq 1,96$ menunjukkan terdapat pengaruh yang signifikan pada variabel entrepreneurial leadership terhadap kinerja organisasi. Sedangkan nilai koefisien estimate yaitu sebesar 0,472. Koefisien tersebut memiliki nilai positif, yang memiliki arti semakin baik gaya kepemimpinan kewirausahaan yang dimiliki maka hal tersebut akan mendorong peningkatan kinerja organisasi UMKM Binaan Dinas Koperasi dan Usaha Mikro Kota Surabaya. Sehingga $\mathrm{H}_{1}$ diterima.

Tabel 4

Uji Kausalitas Hasil Path Coefficients

\begin{tabular}{ccccc}
\hline $\begin{array}{c}\text { Hubungan Antar } \\
\text { Variabel }\end{array}$ & $\begin{array}{c}\text { Original } \\
\text { Sample }\end{array}$ & T-Statistics & Keterangan & Kesimpulan \\
\hline $\begin{array}{c}\text { Entrepreneurial Leadership } \\
\rightarrow \text { Kinerja UMKM }\end{array}$ & 0.472 & 2.072 & $\begin{array}{c}\geq 1.96 \\
\text { (Signifikan) }\end{array}$ & $\begin{array}{c}\text { Hipotesis } \\
\text { diterima }\end{array}$ \\
\hline $\begin{array}{c}\text { Entrepreneurial Leadership } \\
\rightarrow \text { Inovasi Produk }\end{array}$ & 0.453 & 2.157 & $\begin{array}{c}\geq 1.96 \\
\text { (Signifikan) }\end{array}$ & $\begin{array}{c}\text { Hipotesis } \\
\text { diterima }\end{array}$ \\
$\begin{array}{c}\text { Inovasi Produk } \rightarrow \text { Kinerja } \\
\text { UMKM }\end{array}$ & 0.124 & 0.458 & $\begin{array}{c}\leq 1.96 \text { (Tidak } \\
\text { Signifikan) }\end{array}$ & $\begin{array}{c}\text { Hipotesis } \\
\text { ditolak }\end{array}$ \\
\hline
\end{tabular}

Sumber: Output SmartPLS 3.0 
H2 menduga bahwa kepemimpinan kewirausahaan berhubungan positif dengan inovasi produk. Hubungan antar variabel pada tabel 4 dapat dijelaskan besarnya nilai $t$-Statistics pengaruh entrepreneurial leadership terhadap inovasi produk sebesar 2,157 $\geq 1,96$ yang menunjukkan bahwa ada pengaruh yang signifikan antara variabel entrepreneurial leadership terhadap inovasi produk. Sedangkan nilai koefisien estimate sebesar 0,453 . Koefisien tersebut memiliki nilai positif yang artinya apabila entrepreneurial leadership semakin tinggi maka inovasi produk akan semakin tinggi pula, begitu juga sebaliknya. Sehingga $\mathrm{H}_{2}$ diterima.

H3 menduga bahwa inovasi produk secara positif terkait dengan kinerja organisasi. Adapun besarnya nilai t-Statistics pengaruh inovasi produk terhadap kinerja organisasi sebesar $0,458 \leq 1,96$ menunjukkan bahwa tidak ada pengaruh pada variabel inovasi produk terhadap kinerja UMKM Binaan Dinas Koperasi dan Usaha Mikro Kota Surabaya. Sedangkan, nilai koefisien estimate sebesar 0,124. Koefisien tersebut memiliki nilai positif yang berarti walaupun UMKM Binaan Dinas Koperasi dan Usaha Mikro Kota Surabaya telah memiliki inovasi produk yang baik/tinggi, hal tersebut tidak berdampak apapun terhadap kinerja UMKM Binaan Dinas Koperasi dan Usaha Mikro Kota Surabaya. Sehingga $\mathrm{H}_{3}$ ditolak.

Selain itu, analisis bootstraping menunjukkan bahwa pengaruh tidak langsung yaitu inovasi produk tidak signifikan pada hubungan ini. Oleh karena itu, dapat disimpulkan bahwa efek mediasi dari pengaruh tidak langsung (inovasi produk) tidak signifikan secara statistik, dan ini memberikan informasi bahwa inovasi produk gagal memediasi baik secara parsial maupun secara penuh pada hubungan antara kepemimpinan wirausaha dan kinerja organisasi.

Tabel 5 menunjukkan bahwa besarnya koefisien pengaruh langsung entrepreneurial leadership terhadap kinerja UMKM Binaan Dinas Koperasi dan Usaha Mikro Kota Surabaya yaitu 0,472 yang mempunyai makna positif dan signifikan pada 2,072 (nilai $t$ hitung $\geq \mathrm{t}$ tabel 1,96) yang dapat disimpulkan bahwa entrepreneurial leadership berpengaruh secara langsung terhadap kinerja organisasi.

$\mathrm{H}_{4}$ menyatakan bahwa inovasi produk memediasi hubungan antara kepemimpinan kewirausahaan dan kinerja organisasi. Nilai pengaruh entrepreneurial leadership terhadap kinerja organisasi melalui inovasi produk sebesar 0,056 yang memiliki makna positif, namun tidak signifikan 0,409 (nilai thitung $\leq$ 1,96) yang menunjukkan bahwa tidak ada pengaruh antar variabel. Kaitannya dengan hubungan langsung, menunjukkan bahwa entrepreneurial leadership secara langsung berpengaruh positif terhadap kinerja organisasi, nilai koefisien langsung lebih tinggi daripada koefisien pengaruh entrepreneurial leadership terhadap kinerja organisasi melalui inovasi produk. Sehingga dapat disimpulkan bahwa inovasi produk gagal berperan sebagai variabel yang memediasi pengaruh antara entrepreneurial leadership terhadap kinerja organisasi pada UMKM Binaan Dinas Koperasi dan Usaha Mikro Kota Surabaya. Sehingga $\mathrm{H}_{4}$ ditolak.

Tabel 5

Pengaruh Langsung dan Tidak Langsung

\begin{tabular}{lllll}
\hline \multicolumn{1}{c}{ Pengaruh Antar Variabel } & $\begin{array}{c}\text { Original } \\
\text { Sample (O) }\end{array}$ & $\begin{array}{c}\text { T } \\
\text { Statistics }\end{array}$ & Keterangan & Kesimpulan \\
\hline \hline $\begin{array}{l}\text { Entrepreneurial Leadership } \\
\rightarrow \text { Kinerja UMKM }\end{array}$ & 0.472 & 2.072 & $\geq 1.96$ & $\begin{array}{l}\text { Hipotesis } \\
\text { diterima }\end{array}$ \\
\hline $\begin{array}{l}\text { Entrepreneurial Leadership } \\
\rightarrow \text { Inovasi Produk } \rightarrow \text { Kinerja }\end{array}$ & 0.056 & 0.409 & $\begin{array}{l}\leq 1.96 \text { (Tidak } \\
\text { Signifikan) }\end{array}$ & $\begin{array}{l}\text { Hipotesis } \\
\text { ditolak }\end{array}$ \\
UMKM & & & & \\
\hline
\end{tabular}

Sumber: Output SmartPLS 3.0 


\section{PEMBAHASAN}

Kepemimpinan kewirausahaan adalah paradigma yang relatif muncul serta telah diterapkan untuk mengatasi sifat organisasi yang selalu berubah dan dinamis saat ini. Jenis kepemimpinan ini telah mendapat perhatian yang meningkat dari para sarjana dan praktisi karena pentingnya dalam meningkatkan daya saing, kesuksesan dan pertumbuhan semua jenis bisnis (Bagheri et al., 2020; Cai et al., 2018; Clark et al., 2019; Freeman dan Siegfried, 2015) dan organisasi publik atau swasta (Bagheri dan Akbari, 2018; Kim et al., 2017; Miao et al., 2018).

Indonesia membutuhkan sedikitnya 4 juta wirausaha baru untuk turut mendorong penguatan struktur ekonomi. Sebab, saat ini rasio wirausaha di dalam negeri masih sekitar 3,1 persen dari total populasi penduduk. "Maka itu, agar Indonesia menjadi negara maju, pemerintah terus memacu pertumbuhan wirausaha termasuk industri kecil dan menengah (IKM), sekaligus meningkatkan produktivitas dan daya saingnya di era digital," kata Menteri Perindustrian Airlangga Hartarto pada acara Pesta Retail Nasional di ICE BSD, Tangerang, Kamis (22/11/18) malam.

Kepemimpinan kewirausahaan merupakan gabungan antara kepemimpinan orientasi kewirausahaan dan manajemen kewirausahaan (Musa dan Fontana, 2014). Meskipun rasio wirausaha di Indonesia sudah melampaui standar internasional, yakni sebesar 2 persen, Indonesia perlu menggenjot lagi untuk mengejar capaian negara tetangga. Misalnya, Singapura saat ini sudah mencapai angka 7 persen, sedangkan Malaysia berada di level 5 persen. Apabila dihitung dengan populasi penduduk Indonesia sekitar 260 juta jiwa, jumlah wirausaha nasional mencapai 8,06 juta jiwa (Kemenperin, 2018).

Hasil pendataan pada Sensus Ekonomi tahun 2016 (SE2016) Kota Surabaya terhimpun sebesar 382.768 usaha/perusahaan non pertanian yang dikelompokkan kedalam 17 kategori lapangan usaha, hal ini meningkat $5 \%$ dibandingkan dengan hasil pendataan
Sensus Ekonomi tahun 2006 (SE06) yang berjumlah sebesar 362.454 usaha/perusahaan. Bila dikelompokkan menurut skala usaha yang dijalankan, sebesar 365.071 usaha/ perusahaan (95\%) berskala Usaha Mikro Kecil (UMK) serta 17.697 usaha/perusahaan (5\%) berskala Usaha Menengah Besar (UMB).

Sebaran jumlah usaha/perusahaan pa da antar kecamatan menunjukkan bahwa sebesar 31.227 usaha/perusahaan skala UMK berada di Kecamatan Semampir atau dengan kata lain 8,6\% terhadap jumlah usaha/perusahaan skala UMK di Kota Surabaya. Disusul oleh Kecamatan Sawahan sebanyak 24.512 usaha $(6,7 \%)$, serta Kecamatan Kenjeran sebanyak 21.069 usaha $(5,8 \%)$ terhadap jumlah usaha/perusahaan skala UMK yang ada di Kota Surabaya (Badan Pusat Statistik Kota Surabaya, 2018).

Entrepreneurial leadership ialah salah satu gaya kepemimpinan yang sangat perlu untuk dimiliki setiap pemilik UMKM Binaan Dinas Koperasi dan Usaha Mikro Kota Surabaya dalam menunjang kinerja usahanya. Hal ini perlu sangat diperhatikan karena entrepreneurial leadership ialah gaya kepemimpinan yang dapat memengaruhi orang lain dengan cara komunikasi yang efektif terhadap setiap karyawan, serta untuk dapat mengidentifikasi setiap peluang dan ancaman sehingga dapat digunakan untuk mempertahankan daya saing suatu usaha.

Entrepreneurial leadership juga dapat berhubungan dengan pemimpin yang dapat mengambil beban tanggung jawab untuk organisasi masa depan, hal ini tercermin pada indikator absorbing uncertainty. Hal ini membuat pemilik UMKM Binaan Dinas Koperasi dan Usaha Mikro Kota Surabaya berani untuk mengambil resiko dalam usaha kedepannya, melalui pembuatan keputusan dengan cara mencoba suatu hal baru yang diharapkan dapat berakibat pada peningkatan kinerjanya.

Entrepreneurial leadership juga mempengaruhi kinerja organisasi usaha dalam hal kemampuan menegosiasikan suatu gagasan 
dan penciptaan ide untuk menetapkan rencana kedepannya. Kemampuan tersebut dapat berupa piawai berkomunikasi dengan pihak lain (konsumen), memengaruhi orang lain dari pandangan pemilik usaha, serta dapat mendorong karyawan untuk memiliki kepercayaan diri.

Berdasarkan wawancara dari pemilik UMKM Binaan Dinas Koperasi dan Usaha Mikro Kota Surabaya yaitu Ibu Aminah, menyatakan bahwa beliau sering menceritakan bagaimana kondisi usahanya tersebut kepada seluruh karyawannya, hal tersebut dimaksudkan agar karyawan menjadi termotivasi dalam menyelesaikan tugas-tugasnya, serta memiliki kepercayaan tinggi dalam dirinya, bahkan Ibu Aminah merasa senang jika suatu saat para karyawannya mampu menciptakan usaha sendiri.

Selain itu, proses komunikasi yang efektif dengan beberapa pihak menjadikan UMKM Binaan Dinas Koperasi dan Usaha Mikro Kota Surabaya: Selendang Semanggi yang dijalankan Ibu Aminah ini maupun UMKM Binaan Dinas Koperasi dan Usaha Mikro Kota Surabaya yang lainnya cukup sering diundang dalam bazar atau pameran UMKM di Surabaya.

Berdasarkan hal tersebut membuktikan bahwa karyawan serta beberapa pihak eksternal merupakan faktor yang memengaruhi kinerja organisasi UMKM Binaan Dinas Koperasi dan Usaha Mikro Kota Surabaya, serta kemampuan yang dimiliki pemilik UMKM Binaan Dinas Koperasi dan Usaha Mikro Kota Surabaya dalam membangun hubungan para karyawan dan pihak eksternal yaitu dalam hal peran building commitment serta specifying limits sebagai salah satu indikator entrepreneurial leadership yang diharapkan dapat meningkatkan kinerja suatu usaha agar dapat lebih baik.

Berdasarkan temuan, hasil penelitian ini juga mendukung penelitian yang telah dilakukan oleh Rahim et al., (2015) yang menghasilkan hasil terdapat pengaruh positif antara entrepreneurial leadership terhadap organizational performance pada pemilik UMKM di Malaysia. Pemilik UMKM Binaan Dinas Koperasi dan Usaha Mikro Kota Surabaya harus lebih mengadaptasi contoh gaya kepemimpinan tersebut untuk dapat meningkatkan kinerja dari organisasinya melalui proses pemahaman hubungan antara keduanya. Berdasarkan temuan, hasil penelitian ini juga sama dengan penelitian yang telah dilakukan oleh Mgeni dan Nayak (2015), penelitian tersebut menghasilkan bahwa $68.88 \%$ CEO di Tanzania menggunakan gaya kepemimpinan entrepreneurial leadership yang telah terbukti berdampak positif tehadap kinerja bisnis pada UKM di Tanzania.

Pengembangan kepemimpinan manajerial, sesuai dengan kebutuhan lingkungan persaingan, merupakan salah satu tujuan dari semua organisasi. Setiap organisasi dibekali dengan orang-orang dalam kemampuan kewirausahaan, yang dapat dikembangkan dengan dukungan yang memadai. Dukungan yang tepat dari organisasi menumbuhkan perilaku kewirausahaan di antara manajer mereka dalam posisi kepemimpinan (Mirkamandar dan Malikehbeheshtifar, 2015). Berbagai faktor dalam organisasi memainkan peran penting dalam mengembangkan gaya kepemimpinan. Dari perspektif kepemimpinan kewirausahaan, lingkungan organisasi dan inovasi memiliki pengaruh yang kuat (Kurtessis et al., 2017; Lope Pihie dan Bagheri, 2013).

Analisis berikutnya gaya kepemimpinan entrepreneurial leadership yang diterapkan pemilik UMKM Binaan Dinas Koperasi dan Usaha Mikro Kota Surabaya mampu memengaruhi inovasi produk pada usaha yang dijalankan. Inovasi yang dilakukan oleh UMKM Binaan Dinas Koperasi dan Usaha Mikro Kota Surabaya berupa inovasi produk. Berdasarkan hasil analisa deskriptif penilaian responden, menunjukkan rata-rata nilai indikator untuk incremental innovation menjelaskan bahwa inovasi yang dilakukan oleh pemilik UMKM Binaan Dinas Koperasi dan Usaha Mikro Kota Surabaya rata-rata 
merupakan suatu penciptaan produkproduk baru maupun pengembangan produk baru yang sudah ada di pasaran, seperti halnya pada perubahan atau memperbaiki tampilan produk dari segi bentuk maupun model, termasuk pelayanan serta cara pemasaran yang digunakan guna melengkapi produk-produk yang telah ada sebelumnya.

Gaya kepemimpinan entrepreurial leadership pada pemilik UMKM Binaan Dinas Koperasi dan Usaha Mikro Kota Surabaya berperan dalam menciptakan inovasi tersebut. Implementasi tersebut dapat dilihat dari banyaknya UMKM Binaan Dinas Koperasi dan Usaha Mikro Kota Surabaya yang mempunyai produk-produk baru namun produk tersebuat adalah hasil dari pengembangan produk yang sudah ada. Hal tersebut telah sesuai berdasarkan hasil wawancara dengan beberapa pemilik UMKM Binaan Dinas Koperasi dan Usaha Mikro Kota Surabaya, mereka menuturkan bahwa mereka berinovasi pada produkproduk mereka dengan produk yang sudah ada sebelumnya di pasaran, namun produkproduk tersebut memilki rasa dan kemasan yang cukup berbeda.

Sedangkan, berdasarkan hasil yang ditunjukkan dari proses analisis deskriptif penilaian responden menunjukkan bahwa rata-rata nilai indikitor untuk radical innovation cukup tinggi, namun nilai indikator tersebut relatif lebih rendah dibandingkan dengan nilai indikator incremental innovation, yang berarti ada beberapa pemilik UMKM Binaan Dinas Koperasi dan Usaha Mikro Kota Surabaya yang menciptakan ataupun memperkenalkan sebuah produk baru dengan menggunakan teknik produksi yang baru pula yang bertujuan untuk membuka peluang usaha baru, namun cukup disayangkan hanya sedikit UMKM Binaan Dinas Koperasi dan Usaha Mikro Kota Surabaya yang berani untuk melakukan hal tersebut. Akan tetapi, hal tersebut membuktikan bahwa entrepreneurial leadership tetap cukup memiliki peran penting dalam menciptakan inovasi produk baru yang telah dijalankan oleh pemilik
UMKM Binaan Dinas Koperasi dan Usaha Mikro Kota Surabaya.

Berdasarkan temuan, hasil penelitian ini juga mendukung penelitian sebelumnya yang telah berhasil dilakukan oleh Fontana et al., (2017), bahwa terdapat pengaruh positif antara entrepreneurial leadership dengan inovasi yang didukung dengan model bahwa organisasi akan jauh lebih efektif melalui penerapan gaya kepemimpinan ini. Hasil tersebut juga sesuai dengan hasil penelitian yang dilakukan oleh Yusnita dan Wahyudin (2017), menunjukkan bahwa entrepreneurial leadership berpengaruh positif dan signifikan terhadap kapasitas inovasi, sehingga hal tersebut diharapkan agar entrepreneurial leadership nantinya dijadikan sebagai upaya untuk meningkatkan kinerja UMKM di era MEA.

Hasil penelitian yang telah dilakukan oleh Kusmintarwanto (2014) juga menyatakan bahwa entrepreneurial leadership berpengaruh positif dan signifikan terhadap product innovation. Hasil penelitian tersebut juga selaras dengan penelitian yang dilakukan oleh Tanutama dan Ardianti (2013) yang menghasilkan bahwa kemampuan entrepreneurial leadership pengusaha mikro dan kecil di Jawa Timur sebagian besar merupakan orang yang cukup visioner, yang dibuktikan dengan seringnya melakukan berbagai inovasi produk-produk baru.

Namun, berdasarkan hasil penelitian ini, inovasi produk tidak memengaruhi kinerja organisasi UMKM Binaan Dinas Koperasi dan Usaha Mikro Kota Surabaya. Besarnya inovasi suatu produk yang dilakukan tidak akan mempengaruh kinerja UMKM Binaan Dinas Koperasi dan Usaha Mikro Kota Surabaya. Besar kecilnya inovasi produk yang telah dilakukan oleh pemilik UMKM Binaan Dinas Koperasi dan Usaha Mikro Kota Surabaya tidak berpengaruh terhadap kinerja UMKM Binaan Dinas Koperasi dan Usaha Mikro Kota Surabaya.

Berdasarkan temuan, hasil ini mendukung penelitian yang dilakukan Hartini (2012), yang menghasilkan hasil 
bahwa inovasi produk tidak berpengaruh terhadap kinerja perusahaan. Hal ini dapat terjadi karena inovasi produk yang dilakukan tidak berdampak pada perubahan kinerja perusahaan yang disebabkan oleh para pesaing maupun followers dapat secara cepat meniru inovasi produk yang dilakukan oleh para karyawan. Hal ini juga berdampak pada para konsumen yang tidak dapat merasakan inovasi produk secara langsung, sehingga hanya dengan melihat kualitas produk sebagai output dari proses inovasi produk.

Sehingga, hal tersebut berakibat pada inovasi produk-produk yang telah dilakukan tidak dianggap istimewa, hal tersebut menyebabkan inovasi tidak dapat berdampak pada profitabilitas dan pertumbuhan usaha. Berdasarkan temuan penelitian, hasil dari penelitian ini juga selaras dengan hasil penelitian yang telah dilakukan oleh Bayus et al., (1997), menghasilkan bahwa inovasi yang telah dilakukan perusahaan kemungkinan tidak akan berpengaruh terhadap kinerja perusahaan yang disebabkan karena para pesaing dengan sangat cepat dapat meniru inovasi produk yang telah dilakukan. Namun hasil penelitian ini menolak hasil yang dikemukakan oleh yang dilakukan (Suhag et al., 2017; Samad, 2012; Twaliwi dan Isaac, 2017), yang menyatakan bahwa inovasi secara signifikan meningkatkan kinerja organisasi UMKM.

Hasil indirect effect juga membuktikan bahwa tidak terdapat pengaruh tidak langsung dari inovasi produk pada kaitannya hubungan antara entrepreneurial leadership terhadap kinerja organisasi. Berdasarkan hasil penelitian ini, dengan demikian peran dari gaya kepemimpinan yang telah diterapkan oleh pemilik UMKM Binaan Dinas Koperasi dan Usaha Mikro Surabaya yaitu dalam hal ini adalah entrepreneurial leadership, terbukti cukup diperlukan dalam meningkatkan kinerja organisasi UMKM Binaan Dinas Koperasi dan Usaha Mikro Kota Surabaya, serta dapat berpengaruh secara langsung tanpa adanya inovasi produk sebagai variabel yang memediasi secara penuh antara hubungan variabel keduanya.

Hasil penelitian ini terbukti berdasarkan hasil pengamatan bahwa peran dari entrepreneurial leadership yang dimiliki oleh pemilik UMKM Binaan Dinas Koperasi dan Usaha Mikro Kota Surabaya sudah cukup dapat meningkatkan kinerja organisasi UMKM Binaan Dinas Koperasi dan Usaha Mikro Kota Surabaya. Hasil penelitian ini juga menunjukkan bahwa tanpa adanya proses inovasi produk yang dilakukan oleh pemilik usaha, terbukti dengan sebagian besar UMKM Binaan Dinas Koperasi dan Usaha Mikro Kota Surabaya yang tidak mengedepankan inovasi produk namun hanya meningkatkan kualitas dari produk mereka, usaha mereka tetap memiliki daya saing yang cukup tinggi.

\section{SIMPULAN DAN SARAN}

Dari hasil analisis data serta pengolahan data dan pembahasan yang telah dilakukan, bahwa entrepreneurial leadership berpengaruh signifikan positif terhadap kinerja organisasi. Entrepreneurial leadership berpengaruh signifikan positif terhadap inovasi produk. Inovasi produk tidak berpengaruh terhadap kinerja organisasi. Entrepreneurial leadership tidak berpengaruh terhadap kinerja organisasi melalui inovasi produk.

Berdasarkan hasil kesimpulan tersebut, terdapat masukan untuk meningkatkan entrepreneurial leadership terhadap pemilik UMKM Binaan Dinas Koperasi dan Usaha Mikro Kota Surabaya yaitu perlunya pemilik UMKM Binaan Dinas Koperasi dan Usaha Mikro Kota Surabaya untuk mengikuti setiap program pelatihan yang diselenggarakan oleh Dinas Koperasi dan Usaha Mikro Kota Surabaya maupun lembaga lainnya agar menambah skill pengusaha sehingga usaha yang digeluti dapat terus bersaing di tengah persaingan global seperti saat ini.

Selanjutnya, untuk memaksimalkan kinerja suatu organisasi, perlunya pemilik UMKM Binaan Dinas Koperasi dan Usaha Mikro Kota Surabaya dapat turut hadir dalam acara bazar maupun acara-acara 
lainnya guna memperkenalkan produkproduknya serta memperluas pasar agar dapat membandingkan produk yang dimiliki dengan produk yang dimiliki pesaing. Selain itu, pemilik UMKM Binaan Dinas Koperasi dan Usaha Mikro Kota Surabaya harus lebih berani untuk mengambil keputusan dan menghadapi tantangan untuk terus berinovasi agar produk yang dimiliki dapat memperoleh keuntungan dalam jangka panjang.

Walaupun topik yang dibahas dalam penelitian ini jarang atau bahkan belum pernah diteliti sebelumnya, namun penelitian ini tentunya memiliki beberapa keterbatasan. Seperti halnya rangkaian studi lainnya, penelitian kami bukannya tanpa batasan. Seperti dengan semua study crosssectional, ukuran sampel dalam penelitian ini sengaja dibuat kecil. Ini membatasi generalisasi temuan di populasi yang lebih luas. Selain itu, mengingat luasnya permasalahan dan keterbatasan waktu, maka penelitian ini hanya dilakukan pada UMKM Binaan Dinas Koperasi dan Usaha Mikro Kota Surabaya, sehingga hasil yang diperoleh kurang dapat menyeluruh untuk mendapatkan jawaban karena kemungkinan terjadi perbedaan karakteristik di setiap wilayah.

Peneliti selanjutnya disarankan tidak membatasi lokasi penelitian pada suatu wilayah atau kota tertentu. Responden dalam penelitian ini adalah pemilik UMKM Binaan Dinas Koperasi dan Usaha Mikro Kota Surabaya dengan bidang usaha makanan dan minuman. Sehingga disarankan bagi peneliti selanjutnya untuk meneliti responden dengan berbagai bidang usaha lainnya agar diperoleh hasil yang lebih akurat. Terakhir, pada penelitian selanjutnya dapat menggunakan variabel lain seperti entrepreneurial leadership dapat memengaruhi keunggulan kompetitif (Yusnita dan Wahyudin, 2017) dan entrepreneurial leadership melalui business process management sebagai intervening dapat memengaruhi kinerja operasional (Massudi, 2015).

\section{DAFTAR PUSTAKA}

Anitha, J. 2014. Determinants of Employee Engagement and Their Impact on Employee Performance. International Journal of Productivity and Performance Management 63(3): 308-323.

Badan Pusat Statistik Kota Surabaya. 2018. Hasil Pendaftaran (Listing) Usaha/ Perusahaan Sensus Ekonomi 2016. https://surabayakota.bps.go.id/pressrelease/ 2018/01/08/47/hasil-pendaftaran--listing-usaha-perusahaan-sensus-ekonomi2016.html

Bagheri, A. dan M. Akbari. 2018. The Impact of Entrepreneurial Leadership on Nurses' Innovation Behaviour. Journal of Nursing Scholarship 50(1): 28-35.

Bagheri, A., A. Newman, dan N. Eva. 2020. Entrepreneurial Leadership of CEOs and Employees' Innovative Behavior in High-Technology New Ventures. Journal of Small Business Management: 123.

Bagheri, A. dan Z. A. L. Pihie. 2011. Entrepreneurial Leadership: towards a Model for Learning and Development. Human Resource Development International 14(4): 447-463.

Baregegh, A., J. O. Rowley, dan S. Sambrook. 2009. Towards a Multidisciplinary Definition of Innovation. Management Decision 47: 1323-1339.

Basrowi. 2009. Kewirausahaan, Untuk Perguruan Tinggi. Ghalia Indonesia. Bogor.

Baum, R. J., E. A. Locke, dan K. G. Smith. 2001. A Multidimensional Model of Venture Growth. Academy Of Management Journal 44(2): 292-303.

Bayus, B., S. Jain, dan A. Rao. 1997. Too Little, too Early: Introduction Timing and New Product Performance in the Personal Digital Assistant Industry. Journal Of Marketing Research 34(1): 5063.

Bosma, N., S. Wennekers, dan J. E. Amoros. 2012. Extended Report: Entrepreneurs and Entrepreneurial Employees Across The Globe. London (GB): Global Entrepreneurship Research Association. 
Cai, W., E. I. Lysova, S. N. Khapova, dan B. A. G. Bossink. 2018. Does Entrepreneurial Leadership Foster Creativity among Employees and Teams? The Mediating Role of Creative Efficacy Beliefs. Journal of Business and Psychology 34(2): 203-217.

Cardy, R. L. dan B. Leonard. 2015. Performance Management: Concepts, Skills, And Exercises. Routledge. New York.

Choudhary, A. I., S. A. Akhtar, dan A. Zaheer. 2013. Impact of Transformational and Servant Leadership on Organizational Performance: a Comparative Analysis. Journal of Business Ethics 116(2): 433-440.

Clark, C. M., C. Harrison, dan S. Gibb. 2019. Developing a Conceptual Framework of Entrepreneurial Leadership: a Systematic Literature Review and Thematic Analysis. International Review of Entrepreneurship, 17(3): 347-384.

Femald, L. W., Jr. dan G. T. Solomon. 1996. Entrepreneurial Leadership: Oxymoron or New Paradigm? The Journal of Management Systems 8: 2-16.

Fernald, L., G. T. Solomon, dan Tarabishy. 2005. A New Paradigm: Entrepreneurial Leadership. Southern Business Review 30(2): 1-10.

Fontana, Avanti, dan S. Musa. 2017. The Impact of Entrepreneurial Leadership Measurement Validation on Innovation Management and its Measurement Validation. International Journal of Innovation Science 9(1).

Freeman, D. dan R. L. Siegfried. 2015. Entrepreneurial Leadership in the Context of Company Start-up and Growth. Journal of Leadership Studies 8(4): 35-39.

Ghozali, I. dan H. Latan. 2015. Partial Least Squares Konsep, Teknik, dan Aplikasi Menggunakan Program Smart 3.0 (2nd ed.). Badan Penerbit Universitas Diponegoro. Semarang.

Gunaedi, N. dan A. Kistyanto. 2018. Pengaruh Keterampilan Politik terhadap Kinerja Karyawan melalui Organizational Citizenship Behavior. Jurnal
Ilmu Manajemen 6(4): 1-9.

Gupta, V., I. C. Macmillan, dan G. Surie. 2004. Entrepreneurial Leadership: Developing and Measuring a CrossCultural Construct. Journal of Business Venturing 19(2): 241-260.

Hankinson, A., D. Bartlett, dan B. Ducheneaut. 1997. The Key Factors in the Small Profiles of Small-Medium Enterprise Owner-Managers that Influence Business Performance. International Journal of Entrepreneurial Behaviour And Research 3(3): 94-98.

Hartini, S. 2012. Peran Inovasi: Pengembangan Kualitas Produk dan Kinerja Bisnis. Jurnal Manajemen dan Kewirausahaan 14(1): 63-90.

Hisrich, R. dan M. Grachev. 1996. Entrepreneurial Leadership in the Global Economy: Similarities and Differences. Journal of Management Systems 8(1-4): 29-38.

Hussin, H. 1997. Personal Values and Identity Structures of Entrepreneurs: a Comparative Study of Malay and Chinese Entrepreneurs in Malaysia. Entrepreneurship and SME Research: On Its Way to The Next Millennium: 33-45.

Indawati, N., A. D. Witjaksono, dan A. Kistyanto. 2018. The Impact of Entrepreneurial Leadership and Innovation Process on Innovation Performance. International Journal of Academic Research In Business \& Social Sciences 8(9): 573583.

Jawa Pos. 2019. HIPMI Siap Dongkrak Jumlah Pengusaha Baru di Indonesia. https://www.jawapos.com/Ekonomi/Bisnis/ 28/06/2019/Hipmi-Siap-Dongkrak-JumlahPengusaha-Baru-Di-Indonesia/.

Kemenperin. 2018. Indonesia Butuh 4 juta Wirausaha Baru untuk menjadi Negara Maju Survei: Kewirausahaan Sosial bisa Bangun Ekonomi Kreatif. https:// kemenperin.go.id/Artikel/19926/IndonesiaButuh-4-Juta-Wirausaha-Baru-UntukMenjadi-Negara-Maju 2018.

Kim, M. Y., S. M. Park, dan Q. Miao. 2017. Entrepreneurial Leadership and Orga- 
nizational Innovation: Improving Attitudes and Behaviors of Chinese Public Employees. Public Service Innovations In China, Springer Singapore, Singapore: 151-184.

Kistyanto, A., Budiono, N. Indawati, H. Fazlurrahman, A. Kautsar, dan Z. Rahman. 2018. Food Industry Performance: Entrepreneurial Leadership and Human Capital Perspective. International Journal of Mechanical Engineering And Technology, 9(6): 1199-1208.

Kistyanto, A., Rahman, M.F.W., Adhar Wisandiko, F. dan Setyawati, E.E.P. 2021. Cultural intelligence increase student's innovative behavior in higher education: the mediating role of interpersonal trust. International Journal of Educational Management ahead-ofprint(ahead-of-print): 1-22.

Kotsemir, M. dan D. Meissner. 2013. Conceptualizing the Innovation Process -Trends and Outlook. Higher School of Economics Research Paper No. WP BPR 10/STI/2013.

Kuratko, D. F. 2005. The Emergence of Entrepreneurship Education: Development, Trends, and Challenges. Entrepreneurship Theory E Practice 29(5): 577-598.

Kuratko, D. F. 2007. Entrepreneurial Leadership in the 21st Century: Guest Editor's Perspective. Journal of Leadership \& Organizational Studies, 13(4): 1-11.

Kuratko, D. F. dan J. Hornsby. 1996. Developing Entrepreneurial Leadership in Contemporary Organizations. The Journal of Management Systems 8: 17-29.

Kurtessis, J. N., R. Eisenberger, M. T. Ford, L. C. Buffardi, K. A. Stewart, dan C. S. Adis. 2017. Perceived Organizational Support: a Meta-Analytic Evaluation of Organizational Support Theory. Journal of Management 43(6): 1854-1884.

Kusmintarwanto, F. 2014. Analisa Pengaruh antara Entrepreneurial Leadership dan Product Innovation pada Industri Makanan dan Minuman di Jawa Timur. AGORA 2(2): 1-8.

Leitch, C. M. dan T. Volery. 2017. Entrepre- neurial Leadership: Insights and Directions. International Small Business Journal 35(2): 147-156.

Lippitt, G. L. 1987. Entrepreneurial Leadership: a Performing Art. The Journal of Creative Behaivor 21(3): 264-270.

Lope Pihie, Z. A. dan A. Bagheri. 2013. The Impact of Principals' Entrepreneurial Leadership Behaviour on School Organizational Innovativeness. Life Science Journal 10(2): 1033-1041.

Massudi, M. 2015. Pengaruh Entrepreneurial Leadership dan Good Governance terhadap Operational Performance melalui Business Process Management sebagai Variabel Intervening pada Usaha Kecil Menengah Sentra Batik Tulis Surabaya. Jurnal Ekonomi Dan Bisnis 3: 210-221.

McClelland, D. C. 1961. The Achieving Society. The Free Press. New York.

Mgeni, T. O. dan P. Nayak. 2015. Impacts of Entrepreneurial Leadership Style on Business Performance of Female Owned SMEs in Dar Es Salaam, Tanzania. Journal of Entrepreneurship $\mathcal{E}$ Management 4(2): 1-15.

Miao, Q., N. Eva, A. Newman, dan B. Cooper. 2019. CEO Entrepreneurial Leadership and Performance Outcomes of Top Management Teams in Entrepreneurial Ventures: the Mediating Effects of Psychological Safety. Journal of Small Business Management 57(3): 1119-1135.

Miao, Q., A. Newman, G. Schwarz, dan B. Cooper. 2018. How Leadership and Public Service Motivation Enhance Innovative Behaviour. Public Administration Review 78(1): 71-81.

Mirkamandar, S. dan Malikehbeheshtifar. 2015. The Role of Perceived Organizational Support on Entrepreneurial Behavior. Research Journal of Social Sciences 8: 155-159.

Mokhber, M., G. G. Tan, A. Vakilbashi, N. Aiza, M. Zamil, dan R. Basiruddin. 2016. Impact of Entrepreneurial Leadership on Organization Demand for Innovation : Moderating Role of Emplo- 
yees Innovative Self-Efficacy. International Review of Management and Marketing (IRMM) 6(3): 415-421.

Musa, S. dan A. Fontana. 2014. Measuring Entrepreneurial Leadership in Innovation Management [Conceptual Framework]. The ISPIM Asia-Pacific Innovation Forum 2014. ISPIM, Singapore.

Olson, P. D. dan B. A. Bosserman. 1984. Attributes of The Entrepreneurial Type. Business Horizons: 53-56.

Oyemomi, O., S. Liu, I. Neaga, dan A. Alkhuraiji. 2016. How Knowledge Sharing and Business Process Contribute to Organizational Performance: using the FsQCA Approach. Journal of Business Research 69(11): 5222-5227.

Rahim, H. L., Z. Z. Abidin, S. Mohtar, dan A. Ramli. 2015. The Effect of Entrepreneurial Leadership towards Organizational Performance. International Academic Research Journal of Business and Technology 1(2): 193-200.

Rahman, M. F. W. dan A. Kistyanto. 2019. Hubungan antara Iklim Psikologis terhadap Kinerja Karyawan melalui Kepuasan Kerja. Dinamika Ekonomi Jurnal Ekonomi Dan Bisnis 12(2): 410-429.

Rahman, M. F. W., A. Kistyanto, dan J. Surjanti. 2020. Flexible Work Arrangements in Covid-19 Pandemic Era, Influence Employee Performance: the Mediating Role of Innovative Work Behavior. International Journal of Management, Innovation

Entrepreneurial Research 6(2): 10-22.

Ranto, D. W. 2017. Pengaruh Entrepreneurial Leadership terhadap Product Inovation pada Industri Makanan di Yogyakarta. Jurnal Bisnis, Manajemen, dan Akuntansi 4(1): 13-24.

Renko, M., A. El Tarabishy, A. L. Carsrud, dan M. Brännback. 2015. Understanding and Measuring Entrepreneurial Leadership Style. Journal of Small Business Management 53(1): 54-74.

Samad, S. 2012. International Conference on Asia Pacific Business Innovation and Technology Management-The Influ- ence of Innovation and Transformational Leadership on Organizational Performance. Procedia - Social and Behavioral Sciences 57: 486-493.

Sarabi, A., F. J. Froese, D. H. Chng, dan K. E. Meyer. 2020. Entrepreneurial Leadership and MNE Subsidiary Performance: the Moderating Role of Subsidiary Context. International Business Review 29(3): 1-12.

Selden, S. C. dan J. Sowa. 2004. Testing a Multi-Dimensional Model of Organizational Performance: Prospects and Problems. Journal of Public Administration Research And Theory, 14(3): 395-416.

Semuel, H., H. Siagian, dan S. Octavia. 2017. The Effect of Leadership and Innovation on Differentiation Strategy and Company Performance. Procedia - Social And Behavioral Sciences 237: 1152-1159.

Suendro, G. 2011. Analisis Pengaruh Inovasi Produk melalui Kinerja Pemasaran untuk Mencapai Keunggulan Bersaing Berkelanjutan (Studi Kasus pada Industri Kecil dan Menengah Batik Pekalongan). Jurnal Sains Pemasaran Indonesia X(3): 317-326.

Sugiyono. 2016. Metode Penelitian Kuantitatif, Kualitatif, RED. Alfabeta. Bandung.

Suhag, A. K., S. R. Solango, R. S. A. Larik, M. K. Lakho, dan A. H. Tagar. 2017. The Relationship of Innovation with Organizational Performance. International Journal of Research - GRANTHAALAYAH 5(2): 292-306.

Surabaya. 2017. UKM Dominasi Pergerakan Ekonomi di Jatim. http://surabaya.bisnis. com/Read/20170525/9/96276/UkmDominasi-Pergerakan-Ekonomi-Di-Jatim

Sutrisno, E. 2009. Manajemen Sumber Daya Manusia (1st ed.). Kencana Prenada Media Group. Jakarta.

Tanutama, S. dan R. Ardianti. 2013. Analisa Deskriptif Entrepreneurial Leadership dan Inovasi Produk pada Pengusaha Mikro dan Kecil di Jawa Timur. AGORA 1(3): 1-8.

Tuan, N., N. Nhan, P. Giang, dan N. Ngoc. 2016. The Effects of Innovation on Firm 
Performance of Supporting Industries in Hanoi - Vietnam. Journal of Industrial Engineering and Management 9(2): 413431.

Twaliwi, Z. C. dan O. M. Isaac. 2017. Impact of Innovation on the Performance of Small and Medium Scale Enterprise in Gwagwalada, Abuja. International Journal of Entrepreneurial Development, Education and Science Research 4(1): 3145.

Wang, C. L., D. D. Tee, dan P. K. Ahmed. 2012. Entrepreneurial Leadership and Context in Chinese Firms: a Tale of Two Chinese Private Enterprises. Asia Pacific
Business Review 18(4): 505-530.

Wirajaya, A. 2016. 92 Persen Pertumbuhan Ekonomi Surabaya Ditopang UKM. http://www.enciety.co/92-Persen-

Pertumbuhan-Ekonomi-SurabayaDitopang-Ukm/

Yusnita, M. dan N. Wahyudin. 2017. Entrepreneurial Leadership melalui Kapasitas Inovasi sebagai Upaya Peningkatan Keunggulan Kompetitif UMKM di Era Masyarakat Ekonomi ASEAN (MEA) (Kajian Usaha Mikro di Kabupaten Bangka). Integrated Journal of Business and Economics (IJBE) 1(1): 10-18. 